https://doi.org/10.22364/htqe.2019.11

\title{
ANALYSIS OF FOREIGN LANGUAGE TEXTBOOKS IN TERMS OF TRANSVERSAL SKILLS
}

\author{
Jolanta Zastavnaja \\ University of Latvia, Latvia
}

\begin{abstract}
In Europe in the second half of the $20^{\text {th }}$ century, events such as radical economic and social change, globalisation and its expression in culture, politics, the economy and the environment, and progress in scientific and information technology had an impact on education. At school, today's students must be taught such knowledge and skills so that they can survive and be successful in the changing $21^{\text {st }}$ century.

Preparing students for life and work is in the spotlight in $21^{\text {st }}$ century education. The aim of the study is to explore and analyse the development of transversal skills in English language textbooks and to explore the possibilities in order to evaluate English language textbooks in terms of transversal skills.

In this research, five English textbooks for $1^{\text {st }} 3^{\text {rd }}$ grade were analysed. Qualitative research, descriptive research and content analysis were used in this research.

The author reveals that in the latest English textbooks, issued in 2017 and 2018, there are significantly more tasks, thus creating transversal skills for students. In turn, older English textbooks, issued in 2013, lack tasks based on a transversal skills approach. The result of this study shows which English textbooks of the five the author of this study recommends using at school in terms of their transversal skills.

From this study, the author has created a recommended checklist for teachers in order to analyse foreign language textbooks in terms of communicative skills, collaborative skills, critical thinking and creativity skills.
\end{abstract}

Keywords: checklist, foreign language textbook, transversal skills.

\section{Introduction}

The skills that a student needs in the $21^{\text {st }}$ century are defined by documents published by international agencies such as the European Commission, the Organisation for Economic Cooperation and Development 
(OECD) project The Future of Education and Skills Education 2030, Partnership for the $21^{\text {st }}$ Century, the World Economic Forum, Centre for Curriculum Redesign, and the United Nations Educational, Scientific and Cultural Organisation (UNESCO). These organisations are discussing the skills that students will require in the future, and which should now be included in the learning content (Centre for Curriculum Redesign \& OECD, 2012; European Commission, 2018; OECD, 2018; Scott, 2015).

After graduating from school, today's students must be able to take responsibility for themselves and personal lifelong learning. Students should be determined, informed and creative. They should be active citizens and participate actively in society (Moore, 2013; Redecker et al., 2011).

The primary goal of education is to prepare students for their future lives (Care \& Luo, 2016). For that reason, textbooks in English lessons can be used as a tool for improving students' life skills. Informational textbooks with plentiful sociocultural structures are needed to promote students' life skills. Textbooks are significant because they serve as a key tool in promoting student life skills (Gavela \& Dolores, 2015; Khosravani, Khosravani, \& Khorashadyzadeh, 2014).

According to the results of the OECD and The Programme for International Student Assessment (PISA), the knowledge and skills of 15-year-olds were found to have higher results in those countries where high-quality textbooks were used. In South Korea textbooks are used about 99\% of the time at schools, and in Taiwan that number is $88 \%$ (Barnaby, 2015; Wiggins, 2015). A good textbook is the key to success for any nation (Mikk, 2000).

Considering the digital advantages in the learning process at school, teachers face a dilemma when they have to decide whether to use digital tools such as interactive blackboards, laptops, smartphones or iPads in the learning process. Teachers still rely heavily on their paper textbooks (Sikorova, Horsley, Garcia, \& Rodriguez, 2013). For students, the textbook can be the main source of language learning and independent study (Richards, 2001). High-quality textbooks help students achieve higher results (Oates, 2014; Richards, 2006; Reints \& Wilkens, 2009).

The textbook is an important tool for learning foreign languages at school (AbdelWahab, 2013; Pingel, 2010; Reints, 2013). According to Sawyer's (2008) opinion, foreign language textbooks should be designed in such a way that students are not only educated but also prepared for life by learning different skills.

The aim of this study is to explore and analyse the development of transversal skills in English textbooks and to explore the possibilities in order to evaluate English textbooks in terms of transversal skills. 
Five English textbooks meant for $1^{\text {st }} 3^{\text {rd }}$ grade were analysed in this study. These textbooks are used for teaching English as a second language at schools in Latvia. The following English class books were analysed:

- Bright Ideas, class book I, by C. Palin, issued in 2018, publisher Oxford University Press;

- Family and Friends, class book III, by T. Thompson \& N. Simmons, issued in 2018, publisher Oxford University Press;

- Poptropica, pupil's book 1. English Islands, by S. Malpas, issued in 2017, publisher Pearson Education.

- Incredible English, class book 1. Second Edition, by S. Phillips, issued in 2015, publisher Oxford University Press;

- Happy Street, class book 1, by S. Maidment \& L. Roberts, issued in 2013, publisher Oxford University Press.

In Latvia, the usage of textbooks at schools is determined by the national general education standards that are approved by the Ministry of Education and Science (Izglìitibas un zinātnes ministrija, 2018).

These selected English textbooks for analysis are approved by the Ministry of Education and Science and correspond to the national general education standards in Latvia.

To analyse the textbooks qualitative research, descriptive research and content analysis were used.

After evaluating five English second language textbooks in terms of transversal skills, the author has established a recommended checklist for teachers in order to analyse foreign language textbooks in terms of communicative skills, collaborative skills, critical thinking and creativity skills.

\section{Methodology and Materials}

Based on the classification of educational studies, the type of this study is a descriptive one. A descriptive study provides a scientifically accurate description of the current situation, relationships and educational developments (Geske \& Grīnfelds, 2006).

The author studied and compared transversal skills in five different foreign language textbooks. Content analysis was used to perform a descriptive qualitative study. Content analysis is one of the ways of obtaining data, but in the previous literature, it is also considered as a separate study method. Content analysis is a procedure for compressing and categorising textual, audio or video information to be classified systematically, in a tabular presentation. Content analysis is a quantitative method that allows an individual to process a large amount of information. Content analysis has two levels. At the first level, descriptive analysis of the 
content of the document is performed without analysing the meaning of the content. The second level is the interpretative or latent level, when the meaning of the content and the resulting conclusions are revealed. Content analysis is widely used in textbook analysis (Geske \& Grīnfelds, 2006).

Criterion for selecting these specific textbooks was the fact that they are currently used in primary schools in Latvia to teach English as a second language. In each book the tasks were analysed from units one to five. Four transversal skills (communicative, collaborative, critical thinking and creativity) were analysed in the tasks of the five books.

The analysis of collaborative skills was based on the findings of Purēns (2017) and Hajimohammadi, Mukundan, and Nimehchisalem (2011). They claim that cooperation is promoted in pair work or group work and that a foreign language textbook can be evaluated according the tasks that develop speaking skills. Criteria for collaborative skills were developed. Criteria correspond to the type and name or instruction of the task in order to analyse the types of tasks in the textbooks to see how the tasks develop collaborative skills in students (see table 1).

The analysis of communicative skills was based on the findings of authors Purēns (2017), Richards (2006), and Gomez-Rodriguez (2010). The authors claim that communicative skills develop through speaking, writing, listening and reading skills. The analysis of communicative skills in tasks was based mainly on speaking skills activities. The author of the study has supplemented and developed communicative skills criteria by naming tasks (see table 1).

The analysis of critical thinking was based on Bloom's taxonomy, according to thinking levels and names of tasks (Purēns, 2017).

The names of the tasks have been selected to correspond to the tasks studied in foreign language textbooks (see table 1).

The analysis of creativity was based on Fadel (2017) and his adaption of Nilsson's use of thinking levels such as imitation, variation, combination and transformation.

Criteria for creativity skills has been supplemented and developed by naming tasks (see table 1).

\section{Results and Discussions}

Methods for evaluating a foreign language textbook were developed. These methods allow teachers to evaluate tasks when using a foreign language textbook at school. Using these methods (see table 1), collaborative skills, communicative skills, critical thinking skills and creativity skills were analysed in five foreign language textbook tasks. When studying in practice the tasks of textbooks according to the criteria in table 2 (see table 2), 
the criteria can be used successfully in the evaluation of textbooks in terms of transversal skills. Therefore, as part of good practice, the author recommends a checklist for teachers in order to analyse collaborative skills, communicative skills, critical thinking skills and creativity skills in foreign language textbooks (see table 1).

\section{Table 1. A Recommended Checklist for Teachers in Order to Analyse Foreign Language Textbooks}

\begin{tabular}{|l|l|l|l|}
\hline \multicolumn{1}{|c|}{ Transversal skills (by tasks) } & & & \\
\hline A-Communicative skills & & & \\
\hline $\mathbf{1}$ Mechanical practice & & & \\
\hline $\begin{array}{l}\text { Listening skills: } \\
\text { Listen, point and repeat } \\
\text { Listen and repeat }\end{array}$ & & & \\
$\begin{array}{l}\text { Listen and read the text } \\
\text { Listen and sing a song } \\
\text { Listen and chant the text } \\
\text { Listen and say the tongue twister }\end{array}$ & & & \\
\hline $\begin{array}{l}\text { Speaking skills: } \\
\text { Say the given dialogue } \\
\text { Sing a song }\end{array}$ & & & \\
\hline $\begin{array}{l}\text { Grammar: } \\
\text { Read and say the given grammar pattern }\end{array}$ & & & \\
\hline 2 Meaningful practice & & & \\
\hline $\begin{array}{l}\text { Speaking skills } \\
\text { Ask and answer using the given picture or a phrase } \\
\text { Look at the picture and answer the teachers given } \\
\text { questions } \\
\text { Look at the picture and describe it } \\
\text { Play a board game }\end{array}$ & & & \\
\hline $\begin{array}{l}\text { Listening skills } \\
\text { Watch the video and answer the questions } \\
\text { Listen to a recording and offer answers using the given } \\
\text { pictures }\end{array}$ & & & \\
\hline $\begin{array}{l}\text { Reading skills: } \\
\text { Read the text and answer the questions } \\
\text { Read the text/story/book }\end{array}$ & & & \\
\hline 3 Communicative practice & & & \\
\hline $\begin{array}{l}\text { Speaking skills: } \\
\text { Answer the open-ended questions in the context of } \\
\text { teaching subject topics }\end{array}$ & & & \\
\hline
\end{tabular}




\begin{tabular}{|c|c|c|c|c|}
\hline Transversal skills (by tasks) & 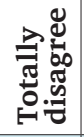 & 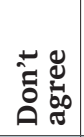 & 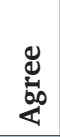 & 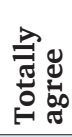 \\
\hline \multicolumn{5}{|l|}{ B-Collaborative skills } \\
\hline $\begin{array}{l}\text { Speaking skills: } \\
\text { Pair work } \\
\text { Dialogue } \\
\text { Ask the questions } \\
\text { Answer the questions } \\
\text { A guessing game } \\
\text { Play a board game in pairs or groups }\end{array}$ & & & & \\
\hline \multicolumn{5}{|l|}{$\begin{array}{l}\text { Speaking skills: } \\
\text { Group work } \\
\text { A boarding game } \\
\text { Act out a story in groups }\end{array}$} \\
\hline \multicolumn{5}{|l|}{ C-Creativity skills } \\
\hline \multicolumn{5}{|l|}{$\begin{array}{l}\text { Imitation level: } \\
\text { Loudly quoting a piece of literary work in front of the class }\end{array}$} \\
\hline \multicolumn{5}{|l|}{$\begin{array}{l}\text { Variation level: } \\
\text { Rewrite a sentence from a literary work, maintaining its } \\
\text { grammatical structure and only changing the words used. }\end{array}$} \\
\hline \multicolumn{5}{|l|}{$\begin{array}{l}\text { Combination level: } \\
\text { Create a machine or other object from figures created } \\
\text { in the classroom. }\end{array}$} \\
\hline \multicolumn{5}{|l|}{$\begin{array}{l}\text { Transformation level: } \\
\text { Create a timeline for historical events that separates } \\
\text { political, social and economic units, using the notes } \\
\text { you have made in the class }\end{array}$} \\
\hline \multicolumn{5}{|l|}{ D-Critical thinking } \\
\hline \multicolumn{5}{|l|}{$\begin{array}{l}\text { Remembering: } \\
\text { Say! Name! } \\
\text { Remember and insert the missing one! }\end{array}$} \\
\hline \multicolumn{5}{|l|}{$\begin{array}{l}\text { Understanding: } \\
\text { Describe using your own words! Describe it! } \\
\text { Arrange in a specific order! } \\
\text { Connect the compatible one! Find what's asked. }\end{array}$} \\
\hline \multicolumn{5}{|l|}{$\begin{array}{l}\text { Application by sample: } \\
\text { Solve by model! Add up! } \\
\text { Find among the given ones! } \\
\text { Choose between the given ones! }\end{array}$} \\
\hline \multicolumn{5}{|l|}{$\begin{array}{l}\text { Analysis: } \\
\text { Say what belongs to this group. }\end{array}$} \\
\hline \multicolumn{5}{|l|}{$\begin{array}{l}\text { Create: } \\
\text { Create from details! }\end{array}$} \\
\hline $\begin{array}{l}\text { Assessment: } \\
\text { Assess by comparing criteria! }\end{array}$ & & & & \\
\hline
\end{tabular}

(Fadel, 2017; Gomez-Rodriguez, 2010; Hajimohammadi et al., 2011; Purēns, 2017; Richards, 2006; the author of this study) 
According to the criteria in table 1, four skills-collaborative, communicative, critical thinking and creativity-were analysed and summarised in tasks of five foreign language textbooks (see table 2). Textbooks were defined as A, B, C, D, and E. To analyse tasks in foreign language textbooks, criteria for each skill in table 1 were used.

Table 2. Transversal skills in five English textbook tasks

\begin{tabular}{|l|c|c|c|c|c|c|}
\hline \multicolumn{1}{|c|}{ Skills } & A & B & C & D & E & Total \\
\hline Collaborative & 27 & 17 & 25 & 19 & 16 & $\mathbf{1 0 4}$ \\
\hline Communicative & 134 & 88 & 90 & 57 & 44 & 413 \\
\hline Critical thinking & 46 & 67 & 63 & 29 & 20 & $\mathbf{2 2 5}$ \\
\hline Creativity & 37 & 56 & 38 & 22 & 29 & $\mathbf{1 8 2}$ \\
\hline Total & $\mathbf{2 4 4}$ & $\mathbf{2 2 8}$ & 216 & 127 & 109 & 924 \\
\hline
\end{tabular}

(author of the study)

According to table 2, it is evident that the tasks are based on the transversal skills approach in all five foreign language textbooks. The results show that the highest number of transversal skills that appear in the tasks are in the following textbooks: $\mathrm{A}=244$ (year 2018), $\mathrm{B}=228$ (year 2018) and $C=216$ (year 2017). Fewer transversal skills are in textbooks $\mathrm{D}=127$ (year 2015) and $\mathrm{E}=109$ (year 2013). The author explains these results by the year of issue of the textbooks. However, it is evident that in the latest textbooks, issued in 2017 and 2018, there are significantly more tasks that create transversal skills for students. In turn, older textbooks, issued in 2015 and 2013, the tasks are less based on a transversal skills approach.

Based on content analysis results and taking into account the spotlight on transversal skills in the $21^{\text {st }}$ century, the author recommends the following foreign language textbooks, A, B, and C, for usage at schools because in these textbooks, the tasks are significantly more based on a transversal skills approach than in the textbooks D and E. Therefore, the author does not recommend textbooks D and $\mathrm{E}$ for usage at schools.

\section{Conclusions}

- The author considers the textbook to be an important tool in the teaching process not only with respect to knowledge but also with regard to communicative, collaborative, critical thinking and creativity skills. 
- The author considers the evaluation of foreign language textbooks to be essential because it enables teachers to choose a textbook that meets the requirements of $21^{\text {st }}$ century education, including tasks that develop transversal skills for students.

- The author has developed methods for evaluating tasks in foreign language textbooks. In practice, the author concludes that these methods can be used successfully in the evaluation of tasks in foreign language textbooks in terms of such transversal skills as communicative, collaborative, critical thinking and creativity skills.

- According to results of this study, the author recommends the following foreign language textbooks, A, B, and C for usage at schools because in these textbooks, the tasks are significantly more based on a transversal skills approach than in the textbooks D and E. Therefore, the author does not recommend textbooks D and E for usage at school.

- Before choosing a foreign language textbook at school, teachers should evaluate the textbooks. Teachers should be convinced that they are using textbooks that include tasks based on a transversal skills approach. Based on this study, the author has created criteria for teachers in order to evaluate tasks in foreign language textbooks in terms of four transversal skills: communicative, collaborative, critical thinking and creativity.

\section{References}

AbdelWahab., M. M. (2013). Developing an English language textbook evaluative checklist. IOSR Journal of Research \& Method in Education, 1(3), 55-70.

Barnaby, L. (2015). Textbooks have a huge impact on education. The Telegraph. Retrieved from https://www.telegraph.co.uk/education/educationopinion/11739310/ Textbooks-have-a-huge-impact-on-education.html

Care, E., \& Luo, R. (2016). Assessment of transversal competencies. Retrieved from https://unesdoc.unesco.org/ark:/48223/pf0000246590

Centre for Curriculum Redesign \& OECD. (2012). $21^{\text {st }}$ century education: What should students learn in the $21^{\text {st }}$ century? Summary and outcomes of Plenary I. Paris. Retrieved from http://curriculumredesign.org/wpcontent/uploads/CCRPlenaryISummary-OutcomesFINAL1.pdf

European Commission. (2018). Proposal for a council recommendation on key competences for lifelong learning. Retrieved from https://ec.europa.eu/education/sites/ education/files/swd-recommendation-key-competenceslifelong-learning.pdf

Fadels, Č., Bialika, M., \& Trilings, B. (2017). 21. Gadsimta skolēns. Četru dimensiju izglitiba (Four-dimensional education). Center for Curriculum Redesign. Lielvārds: Jelgavas Tipogrāfija.

Gavela, F., Dolores, M. (2015). The grammar and lexis of conversational informal English in advanced textbooks. Retrieved from https://www.academia.edu/11188463/ The_Grammar_and_Lexis_of_Conversational_English_in_Advanced_Textbooks 
Geske, A, \& Grīnfelds, A. (2006). Izglïtibas pētniecỉba (Education research). Rīga: LU Akadēmiskais apgāds.

Gomez-Rodriguez, L. F. (2010). English textbooks for teaching and learning English as a foreign language: Do they really help to develop communicative competence? Educacion y Educadores. educ., 13(3). Retrieved from http://www.scielo.org.co/scielo. php? script $=$ sci_arttext\&pid $=$ S0123-12942010000300002\#a1

Hajimohammadi, J., Mukundan, J. Nimehchisalem, V. (2011). Developing an English language textbook evaluation checklist. Contemporary Issues in Education Research, 4(6).

Izglìtības un zinātnes ministrija. (2018). Izglitïbas un zinātnes ministrijas 2017. gada publiskais pārskats (2017 Public report by the Ministry of Education and Science). Retrieved from https://www.izm.gov.lv/images/parskati/2017_IZM_PUBLISKAIS_GADA_PARSKATS. pdf

Khosravani, M., Khosravani, M., and Khorashadyzadeh, A. (2014). Analysing the effects of Iranian EFL textbooks on developing learners' life skills. English Language Teaching Journal, 7(6), 1.

Mikk, J. (2000). Textbook: Research and writing. Frankfurt and Main: Peter Lang GmbH.

Moore, T. (2013). Critical thinking: Seven definitions in search of a concept. Studies in Higher Education, 38 (4), 506-522. Retrieved from https://www.tandfonline.com/loi/ cshe20

Oates, T. (2014). Why textbooks count. Retrieved from https://www.cambridgeassessment. org.uk/Images/181744-why-textbooks-count-tim-oates.pdf

OECD. (2018). The future of education and skills education 2030. Retrieved from https:// www.oecd.org/education/2030/E2030\%20Position\%20Paper\%20(05.04.2018).pdf

Pingel, F. (2010). UNESCO guidebook on textbook research and textbook revision (2 ${ }^{\text {nd }}$ ed.).

Purēns, V. (2017). Kā attistit kompetenci (How to develop a competence). Rīga: RaKa.

Reints, A. J. C., \& Wilkens, H. J. (2009). Evaluating the Quality of textbooks from perspective of learning process. 10th International Conference on Textbooks and Educational Media. IARTEM, 467-474.

Reints, A. J. C. (2013). What works and why? Educational publishing between the market and educational science. $12^{\text {th }}$ International Conference on Textbooks and Educational Media. IARTEM, 16-32.

Redecker, C., Ala-Mutka, K., Leis, M., Leendertse, M., Punie, Y., Gijsbers, G., ... Hoogveld, B. (2011). The future of learning: Preparing for change. Luxembourg: Publications Office of the European Union. Retrieved from http://ftp.jrc.es/EURdoc/ JRC66836.pdf

Richards, C. J. (2001). The role of textbooks in a language program. PAC Journal, 1(1). Retrieved from https://www.researchgate.net/publication/265455920_The_Role_ of_Textbooks_in_a_Language_Program

Richards, J. (2006). Communicative language teaching today. Cambridge: Cambridge University Press. Retrieved from: https://www.professorjackrichards.com/wp-content/ uploads/Richards-Communicative-Language.pdf

Sawyer, R. K. (2008). Optimising learning: Implications of learning science research. Retrieved from https://www.researchgate.net/publication/253490606_Optimising_ Learning_Implications_of_Learning_Sciences_Research. 
Scott, C. L. (2015). The future of learning 2: What kind of learning for the $21^{\text {st }}$ century? UNESCO. Retrieved from https://unesdoc.unesco.org/ark:/48223/pf0000242996

Sikorova, Z., Horsley, M., Garcia T. B., \& Rodriguez J. R. (2013). The Thirteenth International Conference on Research on Textbooks and Educational Media 18-20 September 2013, Ostrava-Czech Republic. University of Ostrova- Facultas Paedagogica: IARTEM.

Wiggins, K. (2015). Teachers, bin your textbooks, says US government official. TES Global Ltd. Retrieved from https://www.tes.com/news/teachers-bin-yourtextbooks-says-us-government-official

\section{The list of analysed foreign language textbooks}

A - Palin, C. (2018). Bright Ideas. Class Book 1. Oxford University Press.

B - Thompson, T., \& Simmons, N. (2018). Family and Friends. Class Book 3. Second Edition. Oxford University Press.

C - Malpas, S. (2017). Poptropica. English Islands. Pupil's Book 1. Pearson Education.

D - Phillips, S. (2015). Incredible English. Class Book 1. Second Edition. Oxford University Press.

E - Maidment, S., \& Roberts, L. (2013). Happy Street. Class Book 1. Oxford University Press. 